Journal of Teacher Education for Sustainability, vol. 15, no. 1, pp. 5-14, 2013

\title{
ENGAGING STUDENT TEACHERS IN SUSTAINABLE PRAXIS IN AOTEAROA/NEW ZEALAND
}

\author{
Sue Smorti, Madeleine Peters-Algie and Cheryl Rau \\ Te Tari Puna Ora o Aotearoa/New Zealand Childcare Association, \\ New Zealand
}

\begin{abstract}
This paper draws on the narratives of three teaching staff as they collaborate to transform student teachers' thinking and praxis about sustainability through a bicultural perspective that acknowledges indigenous and Western ideologies. It will discuss some of the experiences that the student teachers found to be transformational such as: whakapapa (our connectedness to all things, both living and non-living) and a mini action research project on the 'rubbish' generated on their class days. The question the co-researchers pose: How is the [bicultural] conceptual framework visible in our teaching and learning about sustainability? Our findings suggest that student teachers become articulate and passionate about sustainability through engagement in activities that challenge the 'takenfor-granted' everyday practices. As confidence and competence increases, student teachers can realise their potential to make significant curriculum changes as they work alongside children and their families to care for planet earth.
\end{abstract}

Key words: early childhood, teacher education, Māori (indigenous) perspectives, bicultural

\section{Introduction}

The whakatauki or traditional proverb "Mai te kore, ki te pō, ki te whaiāo, ki te āo marama" lies at the heart of a conceptual framework that guides teacher education in the early childhood degree programme of Te Tari Puna Ora o Aotearoa/New Zealand Childcare Association. Students are challenged to become aware of the potential (mai te kore) and the possibilities and uncertainties (ki te pō) as they move into the world of light (ki te whaiāo) towards enlightenment and understanding (ki te āo marama) about their responsibilities as human beings and as teachers of infants, toddlers and young children.

In 2009, our organisation (Te Tari Puna Ora o Aotearoa/New Zealand Childcare Association) developed a bicultural conceptual framework to guide the development of a Bachelor of Teaching (Early Childhood Education) degree with sustainability as a curriculum thread. This provided an opportunity for three members of a teaching team to engage in a dialogue and learn from each other about sustainability from different cultural perspectives. One member of the team in this project is Māori and as tangata 
whenua (indigenous people of the land, Aotearoa/New Zealand) brings a critical lens to effect praxis. Alongside students, co-researchers are challenged to become aware of the potential of integrating a Māori perspective of sustainability moving towards enlightenment and understanding. The question the co-researchers pose is the following: How is the [bicultural] conceptual framework visible in our teaching and learning about sustainability?

This paper outlines a New Zealand historical and contemporary context that has and continues to impact on education for sustainability. Following this is a description of the methodology and research design which is located in both Western and indigenous paradigms. This, then, leads into narrative which links identity and kaitiakitanga (stewardship) of student and lecturer praxis. Analysis of key findings and implications for the New Zealand context conclude the discussion.

\section{Background}

Aotearoa, New Zealand, is a small island nation situated in the South Pacific, where the indigenous people (Māori) are a minority within a total population of 4.4 million (Statistics New Zealand: Tatauranga Aotearoa, 2012). An agreement between two nations, Māori and the British Crown known as the Te Tiriti o Waitangi/the Treaty of Waitangi was signed in 1840. It assured Māori the retention of their lands, belief systems and language (Orange, 1987). This assurance to Māori was not upheld, which has generated a significant loss to language, culture and economic base. This is an ongoing dilemma for Māori. It is of note that the New Zealand government delayed signing the United Nations Declaration on the Rights of Indigenous Peoples (UNDRIP) (United Nations [UN], 2007). Article 15.1 recognises that "indigenous peoples have the right to the dignity and diversity of their cultures, traditions, histories and aspirations which shall be appropriately reflected in education and public information" (UN, 2007, p. 7).

Te Tari Puna Ora o Aotearoa/NZCA policies and a teacher education programme are guided by New Zealand's constitutional document - the Treaty of Waitangi/Te Tiriti o Waitangi (Orange, 1987). Our organisation's bicultural strategy (2008-2010) strengthens this commitment to increase bicultural praxis in the degree. Te Tari Puna Ora o Aotearoa/NZCA provides a field-based teacher education programme whereby student teachers attend class one day a week and work in an early childhood setting for the majority of each week. Many students are mature women with families returning to study. $27 \%$ of students in the programme in 2010 were Māori (Meade, Kirikiri, Paratene, \& Allan, 2011).

\section{An indigenous articulation}

Whakapapa (origins) is an indigenous word representative of Māori beginnings as interconnected beings resonating spiritual, human, physical and environmental elements. The individual is integral to a pedagogical process which recognises that Māori are connected to all things that exist in the universe. "We are linked through our whakapapa to insects, fishes, trees, stones and other life forms" (Mead, 1996, p. 211). Knowing your whakapapa (origins) establishes your place of belonging, the connecting of grandchildren to ancestors, family, subtribes, tribes, to the land, the sea and the mountains. 


\begin{abstract}
Māori knowledge, values and beliefs are bound in the pro-creative pürakaul Māori reality. It is a narrative that highlights qualities of integrity and relatedness to Ranginui (sky father) and Papatuanuku (earth mother), to an intertwined spiritual and cultural relationship with nature. It is within these embedded energies and aspects that Te Ao Māori (Māori worldview) ecological principles reside (Ritchie, Duhn, Rau, \& Craw, 2010, p. 28).
\end{abstract}

The notion of kaitiakitanga (stewardship) is an indigenous cultural conceptualisation which upholds whakapapa (origins), acknowledging interconnectedness through ecological conservation. This term inculcates the emergence of an ethical responsibility to be guardians and trustees of the natural world (Benton, Frame, \& Meredith, 2007). A Māori worldview prioritises the significance of reciprocity and the active engagement of caring for rather than merely caretaking of taonga/treasures (Waitangi Tribunal, 2004).

\title{
Approach to sustainability
}

In New Zealand early childhood settings, children are viewed as "competent, confident learners who ask questions and make discoveries" (Ministry of Education, 1996, p. 88). This allows children to make choices about their engagement in the environment/ curriculum. We would argue this places an additional responsibility on early childhood educators to ensure that all children are provided opportunities to engage in experiences that promote education for sustainability. Furthermore, in a curriculum supported by assessment procedures that focus on children's interests (Ministry of Education, 2004, 2007), it is up to the educator to notice, recognise and respond to children's emerging interests (Cowie, 2000, as cited in Ministry of Education, 2004) in ways that are meaningful to the child. This requires skilful planning and documentation by educators to support children's learning as well as sound content knowledge and pedagogy about the topic of education for sustainability. Increasingly, educator knowledge (or lack thereof) is being fore-fronted in the New Zealand context. Educators need to take personal responsibility for their own environmental knowledge so that education for sustainability becomes an integral part of the early childhood curriculum (Prince, 2010). In a bicultural curriculum such as the New Zealand early childhood curriculum document "Te whāriki: He whāriki mātauranga mō ngā mokopuna o Aotearoa” (Ministry of Education, 1996) it can be expected that this will include consideration of indigenous knowledge as included in the te reo (Māori) text and throughout the remaining document.

Two learning outcomes from "Te whāriki: He whāriki mātauranga mō ngā mokopuna o Aotearoa" (Ministry of Education, 1996) that guide this study include, firstly, the notion that infants, toddlers and young children develop "a relationship with the natural environment and a knowledge of their own place in the environment" (Ministry of Education, 1996, p. 90). On one level, this statement recognises an approach that leans towards environmental education based on children's engagement in the environment. However, when a Māori worldview is applied and concepts such as whakapapa (origins) or kaitiakitanga (stewardship) are considered, then the child becomes an active agent through his/her relationship with the environment. This, then, allows for discussion about issues of social justice and children's competence in acting for the environment. Davis refers to a new conceptualisation as in early childhood education for sustainability (ECEfS) described as: 
transformative early childhood education that values, encourages and supports children as problem-seekers, problem-solvers and action-takers around sustainability issues and topics related to their own lives (Davis, 2009, p. 230).

We argue that this is as relevant to ourselves as co-constructors of knowledge (Jordan, 2009) as it is to our student teachers and teachers in training, and the children and families that they work with in early childhood centres.

The second learning outcome requires that children develop "respect and a developing sense of responsibility for the wellbeing of both the living and the non-living environment as well as (...) develop working theories about the living world and knowledge of how to care for it" (Ministry of Education, 1996, p. 90), again positioning children as active agents in caring for the environment which includes caring for all elements as noted under the concepts of whakapapa (origins) and kaitiakitanga (stewardship) discussed above.

In their study of New Zealand kindergarten children's action competence, Mackey and Vaealiki (2011) argue that young children are critically aware of environmental issues. Elliot and Young (2005) consider the importance of early connection with the natural environment suggesting that environmental education begins at birth, and, on a developmental continuum, such as espoused in "Te whāriki: He whāriki mātauranga mō ngā mokopuna o Aotearoa" (Ministry of Education, 1996), educators are required to consider appropriate learning experiences for infants and toddlers as well as young children.

\section{Methodology}

An eclectic approach utilising indigenous and Western research design (Clandinin, 2007) underpins this study. Kaupapa (philosophy) Māori and narrative research align with a qualitative approach, the emphasis in the study being on dialogue for reflection and change in praxis (Denzin, Lincoln, \& Smith, 2008). Kaupapa Māori methodology upholds narrative/story telling as integral to the transference of values and beliefs across time (King, 2005; Metge, 2010). Kaupapa Māori research recognises its value as a methodological tool, a way of understanding and making sense of people's lives and experiences. Narrative/storytelling aligns with Māori concepts of interconnectedness between whānau (family), hapu (subtribe), iwi (tribe) and the environment. This is affirmed in Ritchie et al. (2010). Linda Smith (1999, p. 120) highlights Māori research principles of:

Kanohi kitea (the face that is seen, being present with people face to face)

Aroha ki te tangata (highlights respect for people)...

Kaua e takahia te mana o te tangata (reminds us to uphold, not trample on the prestige of people) ...

Titiro, whakarongo korero (reminds us to look, listen and speak) ...

Kia tupato (tells us to be cautious) ...

These principles are viewed as rights imbued with ethical underpinnings that honour the integrity of all those involved within research. 
Meier and Stremmel (2010) define narrative research as a "process of studying and understanding experience through story telling or narrative writing” (p. 249). They discuss the application of narrative inquiry to early childhood teacher education as a tool that "prompts reflection and encourages the authentic expression of lived experiences" (p. 250). This suggests that it is through telling of their stories that teachers gain a sense of who are they as teachers and as human beings; one of the core elements in the conceptual framework of the degree is the notion of teacher identity and the relationship of the self as a teacher and the self as a person (Gibbs, 2006). We would add that, in terms of education for sustainability, an acknowledgment of the self as kaitiaki (steward) is an important part of being a teacher and that it is in the acting out of our everyday lives that we express these values.

In her study of self-study research through narrative inquiry, Ajodhia-Andrews (2011) notes the value of collaborative partnerships with colleagues as a way of affording opportunities to construct fresh understandings and thinking, through a shared dialogue with others who may not share familiar perspectives. This has been an important element of our collaboration as we come to know and understand ourselves and the perspectives of others. Moen (2006) emphasises the collaborative nature of narrative research and the importance of a caring relationship between the researcher and those being researched. While this is collaborative research and one colleague is not researching on another, we are exposing our worldviews and values as we share thoughts and ideas and open ourselves to new ways of thinking. Sensitivity to cultural beliefs and values has been an important part of our story telling, supported by a shared responsibility to manaaki (to uphold the prestige of and to care for each other).

Therefore, an indigenous co-researcher's voice illuminates a Māori worldview by exploring philosophical, theoretical and pedagogical understandings alongside fellow co-researchers, both of whom derive their knowledge and understandings from a Western perspective. The co-researchers' philosophical positioning of sustainability, whilst anchored in Western discourse, also aligns with Māori ecological values and beliefs. A praxis of kaitiakitanga (stewardship of the planet) is enacted on a daily basis at the teaching base alongside colleagues and students. A respectful reciprocity exists; the coresearchers upholding the prestige of the earth through deliberate interventions designed to potentialise transformative change of students and staff.

\section{Method}

The opportunities for thinking about sustainability through a new lens occurred as all three researchers shared their reflections; at first informally around the morning tea table and later as we worked together on a shared presentation for the 47th Te Tari Puna Ora o Aotearoa/NZ Childcare Association's conference "Environmental education meets intersecting dispositions: Spaces in student knowledge" (PetersAlgie, Smorti, \& Rau, 2011).

A bicultural research collaborative method was instigated, which involved a multilayered approach whereby two co-researchers would guide and implement the students' inquiry of sustainability. The non-Māori lecturers and their classes were to implement an action research project to investigate the amount of rubbish generated at the teaching base. Following this, the indigenous co-researchers' role was to facilitate conversations to analyse and make visible conceptual understandings of Māori. 
Action research applies cycles of planning, action, observation and reflection. Mukherji and Albon (2010) define action research as "an approach to research that emerges from real-life, practical problems rather than focussing primarily on the development of theory or understanding of an issue" (p. 91). This research method was used with students to gather data on their actions and to plan further interventions which would support sustainable praxis. Students' reflections also form part of the data set.

A limitation of the study was the separation of the indigenous co-researchers from the action research process with the students. Oral narratives are validated by Kaupapa Māori methodology, and the co-researchers applied this as one of the methods used. In Western theory, this may be considered a limitation.

\section{Our approach to teaching and learning about education for sustainability}

At the outset of our co-research collaboration, we were teaching a course that covered a number of key curriculum areas focused on science, technology and environmental science in early childhood settings as well as working in partnership with family and community, with a minor focus on an introduction to practitioner research. Throughout the course, we worked to integrate these areas in meaningful ways as in a holistic curriculum while weaving the theory around the practice.

It was important to us that our students take their learning back into their early childhood centres and communities, which is a notion that fits well within a centrebased model of teacher education such as ours, where students are also practicing teachers. This meant that the experiences we provided must be relevant and meaningful not only to our student teachers, but also to the colleagues in their early childhood centres and to children and families with whom they work. For us, this meant providing 'hands-on' experiences that students could replicate or adapt in their centres, with a particular consideration for infants and toddler programmes.

\section{Findings and analysis}

As a way of modelling the action research component of the course, we involved students in physically collecting and sorting the rubbish generated by them on their class day. The 'problem' we posed to them was: Is the amount of rubbish we generate an issue, and, if so, how could we reduce/reuse/recycle more?

While sorting the rubbish was met with some reluctance initially from class members, the messages from their readings and discussions about sustainability were strong enough to motivate them to engage in the activity. In the first week of the course, with our support, students sorted, weighed, counted and documented visually how much and what type of rubbish they were generating and disposing of in the rubbish bin. This gave us base line data. Each week a small group continued with the research task, documenting and making their findings visible to their classmates. Each student had a turn in the group responsible for recycling over the period of the 10 -week course. This became a self monitoring activity with very little lecturer input after the initial three weeks.

The key change in students' practice on the teaching base was a reduction in refuse from a 50-litre bin to a 10 -litre bin daily. This included a reduction in green waste in the 
rubbish bin. A worm farm made from recycled products was set up and a bokashi bin established when the worms were unable to keep pace with food rubbish.

These findings demonstrated the need for students to have knowledge about the science involved in composting as a way of understanding the conditions conducive for both the worm farm and bokashi bin to operate. As a result of this activity, many of the students returned to their centres and revived discarded worm farms; some made new worm farms from recycled materials with the children. Students also began seeing that children, with teachers' support, are competent and interested in environmental activities, and, for some centres, this meant a move towards integrating these activities into the everyday curriculum offered to children.

The increase in the amount of plastic, glass and metal put out for recycling required some knowledge of the symbols of recycling and learning about what our local council would accept as part of their newly launched recycling project. A visit to the local recycling centre created an awareness of the physical amount of recyclable rubbish created within the city. This gave the students an idea of how their individual actions can collectively impact on the planet, how they can become kaitiaki (stewards) who care for the environment. Students' responses include: The trip to the recycling centre ... seeing it makes it more understandable and real. It makes me think about things I flush down the toilet. As individuals, we can make a difference.

These students' outcomes reflected shifts in thinking; their "kanohi ki te kanohi" (face-to-face) engagement with the 'rubbish' and visit to the 'recycling centre' generating new thinking - a differing relationship anchored in a sense of reciprocity, of taking responsibility and not seeing oneself as separate from the artefacts.

Weekly reflective discussion took place based on the excursion or experience encountered the week before. A passion developed amongst the students for what they were discovering and how they as individuals could make a difference. Many students found out that children attending their centres were already knowledgeable about environmental sustainable practice and were able to engage with families to do more in relation to environmental learning. This also helped strengthen relationships and partnerships within the centre environment.

The group experienced kaitiakitanga (stewardship) as opportunities for thoughts, energies and passions to collude together as a transformed collective. Discussions between colleagues were enriched as our enthusiasm was swept along with our own learning alongside the students. A greater connectedness between participants was established alongside a developing deepened respect for what we all could offer on the topic. Students became passionate about the environment and began to advocate for social justice surrounding environmental sustainability and practice.

There was a deepened connectedness, "Aroha ki te tangata" (caring for people and the environment) enacted resulting in a new student 're-lensed' relationship with their environment. Changes were made to personal choices based on the new knowledge students had gained and after a trip to the waste water treatment plant there was much discussion and seeking out of non-prosperous products in the supermarket. Documentation of the action research provided evidence to reflect upon; sorting the rubbish provided data that indeed the amount of rubbish being generated on the base was a problem. 


\section{Concluding reflections}

Ecological sustainability is a planetary priority, and individual contributions are critical to building a collective consciousness. In this paper, we have drawn from New Zealand literature focusing on sustainability in early childhood, Prince (2010), Ritchie, Duhn, Rau and Craw (2010) and Mackey and Vaealiki (2011). The key tenets of the writers are grounded in advocacy, rights, action competency and indigenous epistemology as integral to kaitiakitanga (stewardship) of the environment.

This research prioritised students' involvement "Titiro, whakarongo...korero" (Look, listen, speak) as integral to a visioning of individual voice adding to the strength of all. As lecturers, we made taken-for-granted assumptions about students' knowledge surrounding sustainable practices before we began these classes. It was not until we engaged in 'real experiences' that students began to understand their personal and professional obligations in this area. Narrative as methodology validates collaboration; as people engage in narrative/storytelling, new visions emerge.

Identity is integral to our conceptual framework. In this research, narrative students came to see themselves as kaitiaki (stewards) taking on the mantle of sustainability and being transformed. Inspired and empowered, the students took their new knowledge and understanding of education for sustainability back into their early childhood centres with strength, voice and a sense of advocacy. Kaitiakitanga (stewardship) was affirmed through establishing a deeper respect for the living and non-living world. Manaakitanga, (caring for all) for the environment was upheld by students' reciprocity towards viewing nature from a newly found ethical position.

The context of Aotearoa/New Zealand as a nation with a dual heritage recognised through Te Tiriti o Waitangi/the Treaty of Waitangi, offers an opportunity to reconceptualise our thinking about sustainability (kaitiakitanga). Co-researchers' collaboration and passion for re-positioning sustainability at the heart of curriculum has inspired transformative praxis that prioritises the collective rather than the individual.

\section{References:}

Ajodhia-Andrews, A. (2010). Reflections of artful experiences in contouring educative and scholarly practices: Self-study analysis through narrative inquiry. International Journal of Learning, 17(11), 111-121.

Benton, R., Frame, A., \& Meredith, P. (Eds.). (2007). Te mātāpunenga: A compendium of references to the concepts and institutions of Māori customary law. Hamilton: Te Mātāhauariki Research Institute at the University of Waikato.

Clandinin, D. J. (Ed.). (2007). Handbook of narrative inquiry. Thousand Oaks, CA: Sage.

Davis, J. (2009). Revealing the research 'hole' of early childhood education for sustainability: A preliminary survey of the literature. Environmental Education Research, 15(2), 227-241.

Denzin, N. K., Lincoln, Y. S., \& Smith, L. T. (2008). Handbook of critical and indigenous methodologies. Los Angeles: Sage.

Elliot, S., \& Young, T. (2005). Environmental education: Connecting with nature. In E. Dau (Ed.), Taking early childhood education outdoors (pp. 144-167). Croydon, Victoria: Tertiary Press. 
Gibbs, C. (2006). To be a teacher: Journeys towards authenticity. Auckland: Pearson Education.

Jordan, B. (2009). Scaffolding learning and co-constructing understanding (2nd ed.). In A. Anning, J. Cullen \& M. Fleer (Eds.), Early childhood education: Society and culture (pp. 39-52) London: Sage Publications Ltd.

King, T. (2005). The truth about stories: A native narrative. Minneapolis: University of Minnesota Press.

Mackey, G., \& Vaealiki, S. (2011). Thinking of children: Democratic approaches with young children in research. Australasian Journal of Early Childhood, 36(2), 8286.

Meade, A., Kirikiri, R., Paratene, D., \& Allan, J. F. (2011). Te Heru : A framework for Māori success within an initial teacher education programme. Wellington: Te Tari Puna Ora o Aotearoa/NZ Childcare Association.

Mead, L. T. T. R. (1996). Ngā aho o te kākahu mātauranga: The multiple layers of struggle by Māori in education. Unpublished doctoral dissertation, the University of Auckland, Auckland, New Zealand.

Meier, D. R., \& Stremmel, A. J. (2010). Reflection through narrative: The power of narrative inquiry in early childhood teacher education. Journal of Early Childhood Teacher Education, 31(3), 249-257. DOI: 10.1080/10901027.2010.500538.

Metge, J. (2010). Kōrero pūrākau: Time and the art of Māori storytelling. In Tuamaka: The challenge of difference in Aotearoa New Zealand (pp. 29-40). Auckland: Auckland University Press.

Mukherji, P., \& Albon, D. (2010). Research methods in early childhood: An introductory Guide. London: Sage.

Ministry of Education. (1996). Te whāriki: He whāriki mātauranga mō ngā mokopuna o Aotearoa: Early childhood curriculum. Wellington: Learning Media.

Ministry of Education. (2004, 2007). Kei Tua o te Pae: Assessment for learning: Early childhood exemplars. Wellington: Learning Media.

Moen, T. (2006). Reflections on the narrative research approach. International Journal of Qualitative Methods, 5(4), 1-11.

Orange, C. (1987). The Treaty of Waitangi. Wellington: Allen and Unwin/Port Nicholson Press.

Peters-Algie, M., Smorti, S., \& Rau, C. (2011, July). Environmental education meets intersecting dispositions: Spaces in student knowledge. 48th Annual NZCA Conference 22-24th July 2011, Rotorua, New Zealand. Te Tari Puna Ora o Aotearoa/ New Zealand Childcare Association (Unpublished report).

Prince, C. (2010). Sowing the seeds: Education for sustainability within the early years curriculum. European Early Childhood Education Research Journal, 18(3), 273284. DOI: 10.1080/1350293X.2010.500082.

Ritchie, J., Duhn, I., Rau, C., \& Craw, J. (2010). Titiro Whakamuri, Hoki Whakamua: We are the future, the present and the past: Caring for self, others and the environment in early years' teaching and learning. Final report for the teaching and learning research initiative. Wellington: Teaching and Learning Research Initiative/New Zealand Centre for Educational Research.

Smith, L. (1999). Decolonizing methodologies: Research and indigenous peoples. London: Zed Books. 
Statistics New Zealand. Tatauranga Aotearoa. (2012). Estimated resident population of New Zealand. Retrieved March 5, 2013, from http://www.stats.govt.nz/ tools_and_services/tools/population_clock.aspx

UN (United Nations). (2007). United Nations Declaration on the Rights of Indigenous Peoples. A/RES/61/295: General Assembly. Retrieved March 5, 2013, from http://www.un.org/esa/socdev/unpfii/documents/DRIPS_en.pdf

Waitangi Tribunal. (2004). Report on the Crown's foreshore and seabed policy. Wai 1071. Retrieved March 5, 2013, from http:/www.waitangi-tribunal.govt.nz/reports/

\section{Correspondence:}

Sue Smorti, senior lecturer, Te Tari Puna Ora o Aotearoa/New Zealand Childcare Association, PO Box 4284, Manawatu Mail Centre, Palmerston North, 4442. 23 Mihaere Drive, Palmerston North 4414. Email: Sue.Smorti@nzca.ac.nz 